\title{
Examination of Helminth Parasites in the Fecal Samples of Magpies (Pica pica), Jackdaws (Corvus monedula), and Rooks (Corvus frugilegus) in the Vicinities of Van Province/Turkey
}

\author{
Ali Bilgin YILMAZ*,1, Erkan AZIZOĞLU², Özdemir ADIZEL ${ }^{3}$
}

\author{
${ }^{1}$ Van Yüzüncü Yil University, Faculty of Health Sciences, 65080, Van, TURKEY \\ ${ }^{2}$ Hakkari University, Çölemerik Vocational School, Department of Plant and Animal Production, 30100, Hakkari, TURKEY \\ ${ }^{3}$ Van Yüzüncü Yil University, Faculty of Science, Department of Biology, 65080, Van, TURKEY \\ ORCID ID: Ali Bilgin YILMAZ: https://orcid.org/0000-0003-0749-2418; Erkan AZİZĞLU: https://orcid.org/0000-0002-4895-4298; Özdemir \\ ADIZEL: https:// orcid.org/0000-0002-0432-0277
}

\begin{abstract}
Received: 06.07.2020
Accepted: 17.09.2020

Published online: 21.09 .2020

Issue published: 31.12 .2020

Abstract: The present study was designed to examine helminths in the gastrointestinal tract of corvid species including Pica pica, Corvus frugilegus, and Corvus monedula. A total of 43 fecal samples were collected from Pica pica, 42 samples from Corvus frugilegus, and 42 samples from Corvus monedula species. Feces were analyzed using sedimentation and flotation methods. Echinostoma spp. (2.32\%), Capillaria spp. (6.97\%), Syngamus spp. (2.32\%), and Raillietina spp. (6.97\%) were detected in Pica pica, Raillietina spp. (2.5\%) and Capillaria spp. (10.0\%) were detected in Corvus monedula, and only Capillaria spp. (9.52\%) were detected in Corvus frugilegus. To our knowledge, this is the first study in Turkey identifying these helminth species in the fecal samples of these bird species.
\end{abstract}

Keywords: Corvidae, Helmint, Pica pica, Corvus frugilegus, Corvus monedula.

\section{Van'da (Türkiye) Saksağan (Pica pica), Cüce Karga (Corvus monedula) ve Ekin Kargası (Corvus frugilegus) Dışkılarının Helmint Parazitler Açısından İncelenmesi}

Öz: Bu çalışma Corvidae ailesine bağlı Saksağan (Pica pica), Cüce karga (Corvus monedula), Ekin kargası (Corvus frugilegus) türü yabani kuşlarda gastrointestinal sistem helmintlerini tespit etmek için yapıldı. Bu amaçla Saksağan'dan 43, Cüce kargadan 40, Ekin kargasından 42 adet dışkı toplandı. Dışkılar sedimantasyon ve flotasyon yöntemleri ile incelendi. İnceleme sonucunda Saksağan'da \% 2.32 oranında Echinostoma spp., \%6.97 oranında \%6.97 oranında Capillaria spp., \%2.32 oranında Syngamus spp., \%6.97 oranında Raillietina spp., Cüce kargada \% 2.5 oranında Raillietina spp., \%10 oranında Capillaria spp., Ekin kargasında \%9.52 oranında Capillaria spp. türü helmint yumurtaları tespit edildi. Dışkı muayenelerinde yumurtalarını tespit ettiğimiz helmint türleri Pica pica, Corvus monedula ve Corvus frugilegus' da, Türkiye'de ilk kez bu çalışma ile bildirilmektedir.

Anahtar kelimeler: Corvidae, Helmint, Pica pica, Corvus frugilegus, Corvus monedula.

\section{Introduction}

Parasites are frequently seen in wild birds and these birds are known to harbor a wide variety of parasites throughout their life span. Nevertheless, there is little documentation of parasites harbored by wild birds and there is no taxonomy for most of these parasites. Moreover, although parasitic protozoa that reside in blood have been investigated extensively due to the ease of collecting blood samples from living birds, little is known about other species such as intestinal parasites (Moore \& Clayton, 1997). The helminth communities of birds are closely associated with water due to their intermediary hosts and these communities are generally more diverse than those of fish and mammal hosts (Kennedy, Bush, \& Aho, 1986; Bush, Aho, \& Kennedy, 1990; Poulin, 1997).

Turkey is home to a wide variety of species due to its geographical location, topographic conditions, habitat biodiversity, and climatic richness (Kiziroğlu, 2001; Balkaya \& Çelikoba, 2005; Akın, 2009). On the other hand, birds play a vital role in the dissemination of parasites and both birds and their hosts are affected by migration and habitat quality (Webb, 2010; Kanarek \& Zalesny, 2014).

The corvid species examined to date have been shown to live in a half-wild state. These species can disseminate in cultivated areas and natural habitats and typically feed on local trash sources and urban dump sites. These animals breed in the wildlife and may also reproduce in urbanized areas and get adapted to these environments. In their daily life, they keep contact with humans and domestic animals by frequently leaving their feces in their living quarters.

This study aimed to examine the helminths in the fecal samples of corvid species including Pica pica, Corvus frugilegus, and Corvus monedula which are commonly seen in urbanized areas in Van province. We also investigated the role of these bird species in infections caused by helminths.

\section{Material and Methods}

Fecal Samples: Samples of the three bird species were collected from their nesting sites at 18 different locations in Van Province between March and May 2019 (Fig. 1).

Samples were collected from the fresh fecal matter underneath the nests of the birds. Throughout the sample collection processes, no contact was made with the birds and no bird was injured. A total of 43 fecal samples were 
collected from P. pica, 42 samples from C. frugilegus, and 42 samples from $C$. monedula species. Birds selected for the study were identified by an expert ornithologist using the relevant literature (Svensson, Mullarney, \& Zatterström, 2009). All the samples were placed in sealed specimen containers with labels indicating the date, location of sample collection, and the species. The samples were transferred to the laboratory on the same day. Feces were analyzed on the same day using sedimentation and flotation methods. In the flotation method, hazelnut-sized feces were homogenized in 33\% Zinc Sulphate in the tube. The top of the tube was covered with a coverslip and after
30 minutes, the coverslip was taken on the slide. In the sedimentation method, the feces were suspended with tap water or saline and filtered. The top liquid was poured after centrifugation at 400-500 $\mathrm{g}$ for 2 minutes. By taking some amount from the sediment, the smear was prepared. The thin layer was coated with another slide and then was examined under a microscope (Leica DM500) at 10× and $40 \times$ objective lens. The helminth eggs detected in the samples were identified based on the literature data and then were photographed (Mshot Md 90) (Kaufman, 1996; Fernando \& Barta, 2008).

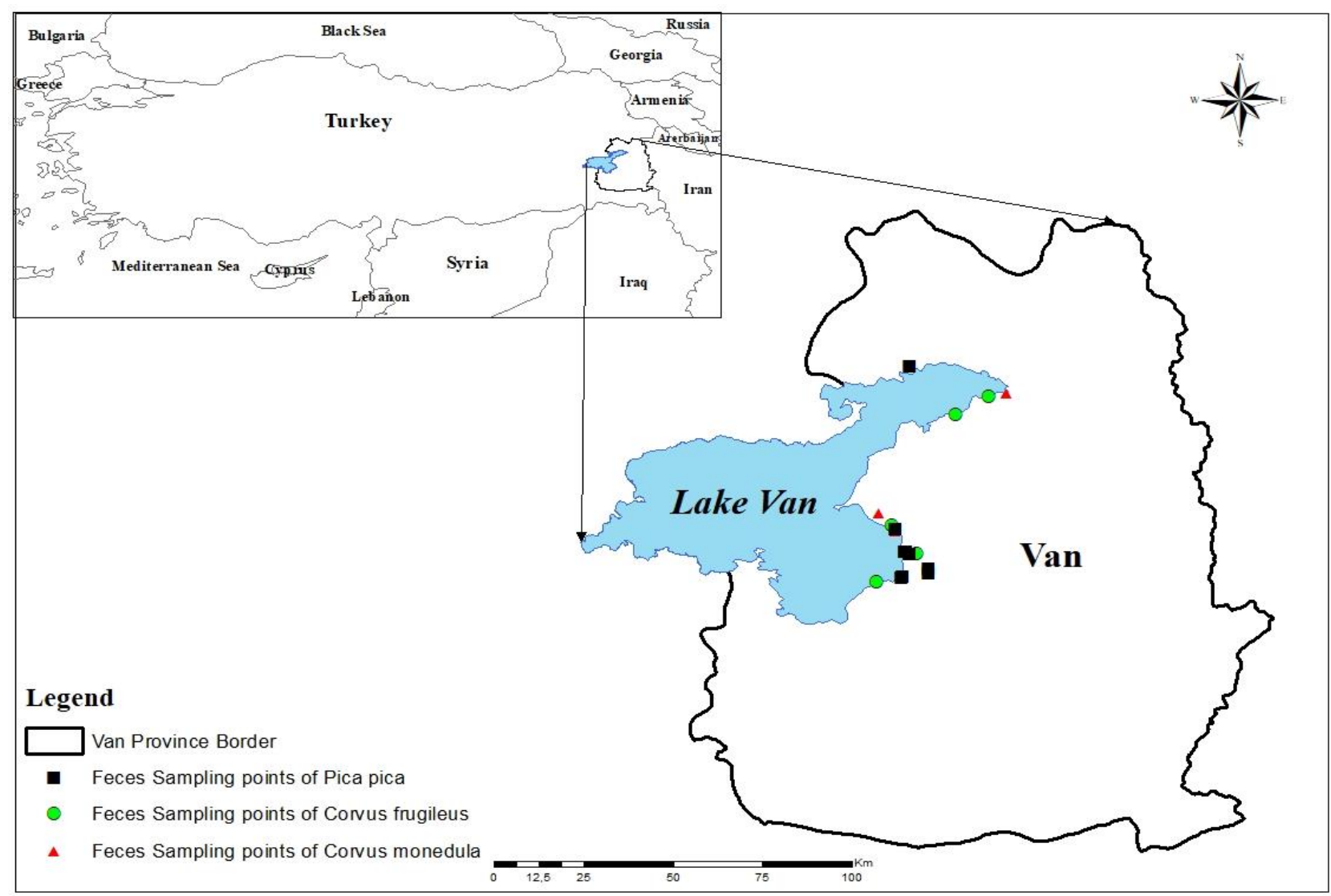

Figure 1. Sample collection sites

\section{Results}

It was revealed that all three corvid species nested on trees in urbanized areas. It was also found that both C. frugilegus and C. monedula established hundreds of breeding and feeding communities, while $P$. pica lived in individual communities. However, the territories of all three species overlapped with each other.

A total of four distinct helminth species were identified in the three bird species. Echinostoma spp., Capillaria spp., Syngamus spp., and Raillietina spp. were detected in Pica pica; Raillietina spp. and Capillaria spp. were detected in C. monedula; and only Capillaria spp. were detected in C. frugilegus (Table 1). The egg sizes of Echinostoma spp., Capillaria spp., Syngamus spp., and Raillietina spp. were $\sim 95 \times 119 \mu \mathrm{m}, \sim 47 \times 25 \mu \mathrm{m}, \sim 92 \times 47 \mu \mathrm{m}$, and $\sim 45 \times 38 \mu \mathrm{m}$, respectively (Fig. 2 ).

\section{Discussion}

Turkey is home to a wide variety of bird species due to its natural features. These species act as hosts to various parasites. The biodiversity of bird species and their hosts are associated with numerous factors such as habitat quality and distribution as well as seasonal changes (Webb, 2010; Kanarek \& Zalesny 2014).

In the present study, Echinostoma spp. were detected as a mixed infection with Capillaria spp. in $2.32 \%(n=1)$ of the fecal samples obtained from $P$. pica species. Similarly, in the previous studies, Echinostoma spp. have been shown to cause severe enteritis in both domestic and wild birds, particularly ducks and geese, by settling down in their cecum and rectum and have also been reported in humans and others mammals, though rarely. (Griffiths, Gonder, \& Pomeroy, 1976; Hossain, Dewan, Baki, \& Mondad, 1980). In Turkey, Echinostoma spp. have been reported in chickens, turkeys, and geese with an infection rate of 0.0610\% (Merdivenci, 1967; Kurt \& Acici, 2008; Güçlü, 1992; Aydın, Göz, \& Değer, 2010). In other countries, however, Echinostoma spp. have been mostly reported in birds and their most common species, E. revolutum, has been reported in ducks, wild water birds, and pigeons (Kaufmann, 1996; Farias \& Canaris, 1986; Yousuf, Das, 
Anisuzzaman, \& Banowary, 2009). Another study detected three Echinostome species including Patagifer bilobus, Petasiger neocomense, and Saakotrema metatestis in wild water birds including Platalea minor, Podiceps cristatus, and Egretta garzetta (Choe et al., 2014). In a previous study conducted in Montana, Todd and Worley (1967) also detected Echinostoma spp. in Pica picahudsonia. Similarly, some previous studies identified Syngamus spp. in the trachea, bronchi, bronchioles, and rarely in the small intestine of numerous birds including chickens, turkeys, geese, guinea fowl, pheasants, peafowls, and quails (Norton \& Ruff, 2003; Fernando \& Barta, 2008). In Turkey, Syngamus spp. have only been reported in chickens with a prevalence of 0.2-3\% (Aydın, Göz, \& Değer, 2010; Kurt \& Acici, 2008). However, in some other countries such as Canada, Britain, Norway, USA, and Czech Republic, Syngamus spp. have been reported in both domestic and wild birds (Fernardo \& Barta, 2008; Okulewica \& Koubek, 1994). In the present study, Syngamus spp. were detected in only $2.32 \%$ of the fecal samples obtained from $P$. pica species. Capillaria spp. are small thin nematodes (hair worms) in the superfamily Trichinelloidea, family Trichuridae, and subfamily Capillarinae. In Turkey, these species have been reported in chickens, geese, ducks, turkeys, domestic and wild pigeons, and sea gulls (Güçlü, 1992; Kurt \& Acici, 2008; Gicık \& Burgu, 2000; Kılınç, Çiçek, \& Akkaş, 2011). In other countries, although Capillaria spp. have been reported in various bird species, these bird species and the infection rates have been shown to vary among countries. To illustrate, Capillaria spp. have been reported in $1.6-54 \%$ of chickens in Denmark, $2-72 \%$ of pheasants and 3-73\% of turkeys in Brazil, and $4-36 \%$ of domestic pigeons in Poland (Permin et al., 1997; Pinto, Tortelly, Menezes, \& Gomes, 2004; Stenzel \& Koncicki, 2007). In our study, Capillaria spp. were detected as a mixed infection with Railletina spp. in $6.97 \%(n=2)$ of the fecal samples obtained from P. pica species. Additionally, Capillaria spp. were detected in $9.52 \%(n=4)$ of the fecal samples obtained from C. frugilegus species and $10 \%(n=4)$ of the fecal samples obtained from C. monedula. In the literature, Raillietina spp. have been shown to settle down in the small intestines of chickens, turkeys, guinea fowls, partridges, quails, and pigeons and to cause weight loss and diarrhea in infected animals (Permin \& Hansen, 1998; Baker, 2007). In Turkey, Raillietina spp. has been reported $3-12 \%$ of chickens, turkeys, partridges, and pigeons (Güçlü, 1992; Kurt \& Acici, 2008; Gicık \& Burgu, 2000; Köroğlu \& Taşan, 1996; Aydın, Göz, \& Değer, 2010). Raillietina spp. is a cosmopolitan species and have been identified in various bird species in Africa, Asia, America, and Europe and is more common in young animals (Permin \& Hansen, 1998; Permin et al., 1997; Magwisha, Kassuku, Kyvsgaard, \& Permin, 2002; Shahin, Lebdah, Abu-Elkheir, \& Elmeligy, 2011; Radfar et al., 2011; Adang et al., 2008). In a study conducted on pigeons in Bursa province, Raillietina echinobothrida species was reported (Yıldırımhan, Gürkan, \& Altunel, 2009). In a postmortem study on $10 \mathrm{P}$. pica in Ankara, it was reported that Dispharonx nasuta nematodes and Trichomonas $s p$. type protozoans were found in one magpie (Çetindağ \& Biyıkoğlu, 1997).

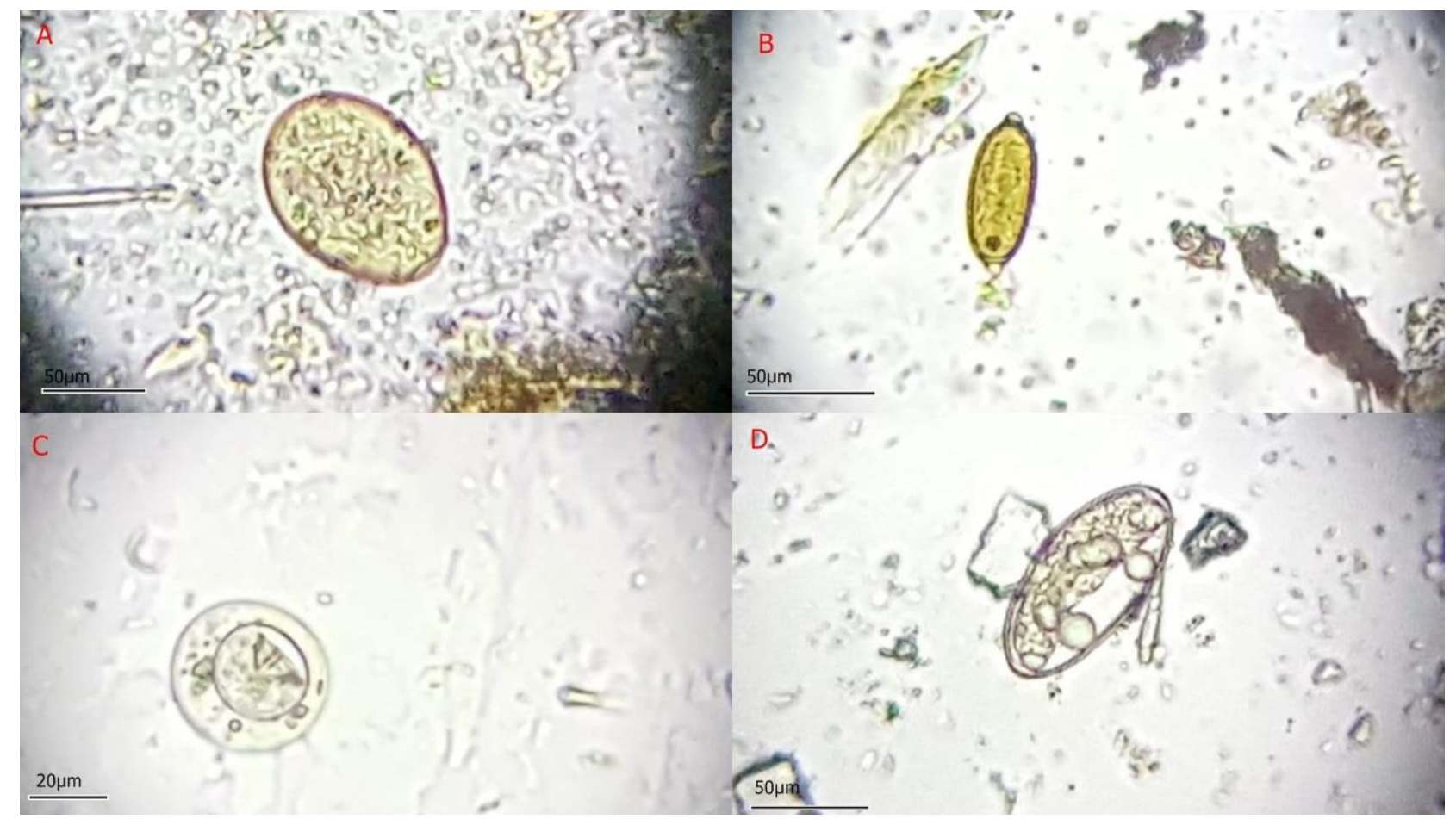

Figure 2. Helminth parasites eggs detected in fecal samples (A: Echinostoma spp. egg, B: Capillaria spp. egg, C: Raillietina spp. egg, D: Syngamus spp. egg)

In our study, however, Raillietina spp. were detected as a mixed infection with Capillaria spp. in a single fecal sample and as a single parasite in two fecal samples obtained from $P$. pica species.

Halajian et al. (2011) evaluated P. pica, C. frugilegus, and C. corone in Iran and diagnosed Syngamus trachea in $6.3 \%$ of P. pica and $6.2 \%$ of C. corone and identified Capillaria spp. in $9 \%$ of C. frugilegus. The differences between these rates and the rates found in our study could be attributed to regional differences and to the fact that Halajian et al. (2011) examined the animals at post mortem. 
Girişgin et al. (2019) conducted a helminthological examination on $P$. pica species at post necropsy and identified Passerilepis spp. and Brachylaima spp. in the animals. Interestingly, these helminth species were not detected in any of the animals examined in our study which could be associated with regional differences and with the fact that Girişgin et al. (2019) only examined eight animals that were brought to the animal hospital for medical intervention. In our study, one trematode (Echinostoma spp.) one cestode (Raillietina spp.), and two nematodes (Capillaria spp. and Syngamus spp.) were identified in the helminth eggs detected in the fecal samples of C. frugilegus, C. monedula, and P. pica species (Table 1). To our knowledge, this is the first study in the literature identifying these helminth species in these bird species.

Table 1. Helminth species identified in the study

\begin{tabular}{lllll}
\hline Bird species & Fecal samples (n) & Positive samples (n) & Helminth species & Infection Rate \\
\hline \multirow{3}{*}{ Pica pica } & & 1 & Echinostoma spp. & $2.32 \%$ \\
& \multirow{2}{*}{43} & 3 & Capillaria spp. & $6.97 \%$ \\
& & 1 & Syngamus spp. & $2.32 \%$ \\
Corvus frugilegus & 42 & 4 & Raillietina spp. & $6.97 \%$ \\
\hline \multirow{2}{*}{ Corvus monedula } & \multirow{2}{*}{40} & 1 & Capillaria spp. & $9.52 \%$ \\
\hline
\end{tabular}

\section{Conclusion}

In conclusion, wild birds harbor a wide variety of parasites throughout their life span and little is known about the importance of infections caused by these parasites in wild birds. Mixed parasitic infections are highly common in wild birds and the effects of these infections on wild birds are associated with the type of the parasite, coexisting parasitic diseases, and stress factors. The results indicated that the corvid species examined in the study had large populations in urbanized areas in the vicinities of Van province which could be related to the abundance of food in those areas. Additionally, this finding could most probably be related to the fact that these species need trees for reproduction and there are almost no trees in the areas other than those areas.

\section{References}

Adang, K.L., Oniye, S.J., Ajanusi, O.J., Ezalor, A.U., \& Abdu P.A. (2008). Gastrointestinal helminths of the domestic pigeons (Columba livia domestica Gmelin, 1789 Aves: Columbidae) in Zaria, Northern Nigeria. Scientific World Journal, 3, 33-37. http:// doi.org/10.4314/swj.v3i1.51769

Akın, G. (2009). Ekoloji (Çevebilim) ve çevre sorunları. Ankara, Tiyden Yayıncilık, 306 pp.

Aydın, A., Göz, Y., \& Değer, S. (2010). Fauna of Helminth in Chickens Grown in Central Villages of Hakkari According to Their Excrement Inspections. Dicle Üniversitesi Veteriner Fakültesi Dergisi, 1, 8-12.

Baker, D.G. (2007). Flynn's parasites of Laboratory Animals. USA, Blackwell Publishing., 784 pp.

Balkaya, N., \& Çelikoba, İ. (2005). Sulak alanlar ve Kızılırmak Deltası. II.Mühendislik Bilimleri Genç Araştırmacılar Kongresi, 17-19 Kasım, İstanbul.

Bush, A.O., Aho, J.M., \& Kennedy, C.R. (1990). Ecological versus phylogenetic determinants of helminth parasite community richness. Evolutionary Ecology Research, 4, 1-20.

Choe, S., Lee, D., Park, H., Oh, M., Jeon, H.K., Lee, Y.,............... \& Eom, K.S. (2014). Three Echinostome Species from Wild Birds in the Republic of Korea. Korean Journal of Parasitology, 52, 513-520. https://doi.org/ $\underline{10.3347 / \mathrm{kjp} .2014 .52 .5 .513}$

Çetindağ, M., \& Biyıkoğlu, G. (1997). Türkiye'de saksağan (Pica pica)'larda Dispharynx nasuta (Rudolphi, 1819) ve Trichomonas sp. bulgusu. Etlik Veteriner Mikrobiyoloji Dergisi, 9, 149-156.

Farias, J.D., \& Canaris, A.G. (1986). Gastrointestinal helminths of the Mexican duck, Anas platyrhynchos Diazı Ridgway, from North Central Mexico and Southwestern United States. Journal Wild Diseases, 22, 51-54.

Fernando, M.A., \& Barta, J.R. (2008). Parasitic Diseases of Wild Birds. England, Blackwell Publishing., 556 pp.

Gıcık, Y., \& Burgu, A. (2000). Ankara ve çevresinde yabani güvercinlerde helmint faunası. Kafkas Üniversitesi Veteriner Fakültesi Dergisi, 6, 1-7.

Girişgin, A.O., Alasonyalılar-Demirer, A., Büyükcangaz, E., Khıder, M., Birlik, S., \& İpek, V. (2019). Postmortem findings on a group of Pica pica
(Passeriformes: Corvidae). Ankara Üniversitesi Veteriner Fakültesi Dergisi, 66, 155-161. https://doi.org/10.33988/AUVFD.547504

Griffiths, H.J., Gonder, E., \& Pomeroy, B.S. (1976). An outbreak of trematodiasis in domestic geese. Avian Disease. 20, 604-606.

Güçlü, F. (1992). The Helminh Fauna in Chickens, Turkeys, Ducks and Geese in the Region of Ankara. (Phd Thesis). Ankara University Graduate School of Health Sciences, Ankara, Turkey.

Halajian, A., Eslami, A., Mobedi, I., Amin, O., Mariaux, J., Mansoori, J., \& Tavakol, S. (2011). Gastrointestinal Helminths of Magpies (Pica pica), Rooks (Corvus frugilegus) and Carrion Crows (Corvus corone) in Mazandaran Province, North of Iran. Iran Journal Parasttology, 6, 38-44.

Hossain, M.I., Dewan, M.C., Baki, M.A., \& Mondad, M.N.H. (1980). Pathology of Echinostoma revolutum infections in pigeons. Bangladesh Journals Online, 14, 1-3.

Kanarek, G., \& Zaleśny, G. (2014). Extrinsic and intrinsic dependent variation in component communities and patterns of aggregations in helminth parasites of great cormorant (Phalacrocorax carbo) from N.E. Poland. Parasitology Research, 113(3), 837-850. https://doi.org/10.1007/ s00436-013-3714-7

Kaufman, J. (1996). Parasitic infections of domestic animals - A Diagnostic Manual. Switzerland Birkhäuser Verlag A.G., 423 pp.

Kennedy, C.R., Bush, A.O., \& Aho, J.M. (1986). Patterns in helminth communities: why are birds and fish different? Parasitology, 93, 205-215.

Kılınç, Ö., Çiçek, M., \& Akkaş, Ö. (2011). Investigation for Helminths of Silver Gull (Larus michahellis) Stool Living Around Van Lake. Van Veterinary Journal, 22, 101-103.

Kiziroğlu, İ. (2001). Birds, Our Flying Friends, Chapter 6. Ecological Potpourri. Ankara, Takav Printing House Publication, 391 pp.

Köroğlu, E., \& Taşan, E. (1996). Distribution of helminths in quails (Coturnix coturnix) and partridges (Alectoris graeca) in the vicinities of Elazığ and Tunceli. Turkesh Journal of Veterinary and Animal Sciences, 20, 241-249.

Kurt, M., \& Acici, M. (2008). Cross-Sectional survey on helminth infections of chicken in the Samsun Region. Dtsch Tierarztl Wochenschr, 115(6), 239242.

Magwisha, H.B., Kassuku, A.A, Kyvsgaard, N.C., \& Permin, A. (2002). A comparison of the prevalence and burdens of helminth infections in growers and adult free-range chickens. Tropical Animal Health and Production, 34, 205-214.

Merdivenci, A. (1967). Türkiye'nin Marmara Bölgesinde evcil tavuk ve kazlarda görülen trematod, sestod ve nematodlara dair araştırmalar. İstanbul, İstanbul Üniversitesi Tip Fakültesi Yayınları, 31.

Moore, J., \& Clayton, D.H. (1997). Host Parasite Evolution: General Principles and Avian Models. Parasitol Today, 14(2), 84.

Norton, R.A., \& Ruff, M.D. (2003). Nematodes and Acanthocephalans. In: Saif, Y.M., Barnes, H.J., Glisson, J.R., Fadly, A.M., McDougald, L.R., and Swayne, D.E. (eds.). Diseases of Poultry. 11th ed. Iowa State University Press, Ames, Iowa. pp. 931-961.

Okulewicz, A., \& Koubek, P. (1994). Nematoda fauna of some charadriiformes from Czech Republic (region Brno). Wiadomosci Parazytologiczne, 40(2), 173-177.

Permin, A., Magwisha, H., Kassuku, A.A., Nansen, P., Bisgaard, M., Frandsen, F., \& Gibbons, L. (1997). A cross- sectional study of helminths in rural scavenging poultry in Tanzania in relation to season and climate. Journal of Helmintology, 71, 233-240. 
Permin, A., \& Hansen S.W. (1998). Epidemiology, diagnosis and control of poultry parasites. Rome Food and Agriculture Organization of the United Nations (FAO), 169 pp.

Pinto, R.M., Tortelly, R., Menezes, R.C., \& Gomes, D.C. (2004). Trichurid nematodes in ring-necked pheasans from backyard flocks of the Stete of Rio de Janeiro, Brazil: frequency and pathology. Memórias do Instituto Oswaldo Cruz, 99, 721-726.

Poulin, R. (1997). Species richness of parasite assemblages: evolution and patterns. Annual Review of Ecology, Evolution, and Systematics, 28, 341358.

Radfar, M.H., Fathi, S., Asl, E.N., Dehaghi, M., \& Seghinsara, H.R. (2011). A survey of parasites of domestic pigeons (Columba livia domestica) in South Khorasan, Iran. Veterinary Research, 4, 18-29. https://doi.org/ $\underline{10.3923 / v r .2011 .18 .23}$

Shahin, A., Lebdah, M., Abu-Elkheir, S.A., \& Elmeligy, M.M. (2011). Prevalence of Chiken Cestodiasis in Egypt. Annals of the New York Academy of Sciences, 4, 321-326.

Stenzel, T., \& Koncicki, A. (2007). Occurance of Parasitic invasions in domestic pigeons (Columba livia domestica) in the Nothern Poland. Polish Journal of Veterinary Sciences, 10, 275-278.

Svensson L., Mullarney, K., \& Zatterström, D. (2009). Collins Bird Guide. London. Harper Collins Publishers Ltd., 85 pp.

Todd, K.S., \& Worley, D.E. (1967). Helminth parasites of the black-billed magpie, Pica pica hudsonia (Sabıne, 1823), From Southwestern Montana. Journal of Parasitology, 53, 364-367.

Webb, E. (2010). Effect of management strategy on waterfowl food availability and selection at wetland reserve program sites in the Mississippi Alluvial Waley, Arkansas Center of Energy, Natural Resources and Environmental Studies Grant Final Report, 1-10.

Yıldırımhan, H.S., Gürkan, E., \& Altunel F.N. (2009). Determination of the helminths of wild pigeons (Columba livia Gmelin, 1789 Columbiformes) in the Bursa region. Türkiye Parazitoloji Dergisi, 33, 321-326.

Yousuf, M.A., Das, P.M., Anisuzzaman, M., \& Banowary, B., (2009). Gastrointestinal helminthes of ducks: Some Epidemiologic and pathologic aspects. Journal of Bangladesh Agricultural University, 7, 91-97. 